\title{
New Simulation Method of New HV Power Supply for Industrial Microwave Generators with $\mathrm{N}=2$ Magnetrons
}

\author{
N.EL GHAZAL, A.BELHAIBA, M.CHRAYGANE, \\ B.BAHANI \\ Laboratory of Materials, Systems and Information of \\ Technology (MSTI), High School of Technology, \\ Ibn Zohr University, BP: 33/S 80000, \\ Agadir-Morocco
}

\begin{abstract}
This original work treats a new simulation method of a new type of high voltage power supply for microwave generators with $\mathbf{N}$ magnetrons (treated case: $\mathbf{N}=2$ magnetrons), used as a source of energy in the industrial applications. This new power supply is composed of a single-phase $\mathrm{HV}$ transformer with magnetic leakage flow, supplying two parallel cells, which multiplies the voltage and stabilizes the current. The doubler supplies one magnetron. The transformer is presented by its $\pi$ equivalent circuit. Each inductance of the model is characterized by its relation "flow-current". In this paper, we present a new approach validation of the $\pi$ model of the special transformer using Matlab-Simulink code. The theoretical results compared with the experimental measurements, is in good agreement with them. The use of this tool Matlab-Simulink, has allowed us to confirm the possibility of the operation of this new system without interaction between magnetrons, with a view to a possible optimization which lead to reduce the weight, the volume and the cost of implementation while ensuring the process of regulating the current in each magnetron.
\end{abstract}

Keywords-Modeling; New Power Supply; Magnetron; Microwave Generator; Matlab-Simulink; High Voltage (HV)

\section{INTRODUCTION}

This work, with industrial character, touches the electrical engineering field for an application hyper frequency linked to the production of the microwave energy. It is within the framework of the development the modeling of manufacturing technologies of power supply for industrial microwave generators and in particular that of his HV transformer with magnetic shunts. This paper discusses a new simulation method modeling a new high-voltage power supply for $\mathrm{N}=2$ magnetrons $800 \mathrm{Watts}-2450 \mathrm{MHz}$ of the figure 1, used as a source of energy microwave. The design of this new power supply uses a HV transformer with magnetic leakage supplying two cell voltage doublers and stabilizers of current [1-13]. The transformer with magnetic shunts ensures the stabilization of average anode current in each magnetron, thanks to the saturation of his magnetic circuit. The trend towards this new power system will be considered a different version of the single-phase model currently manufactured by the manufacturers of the domestic or industrial microwave ovens.

\author{
M.FERFRA \\ Electrical Engineering, Power Electronics Laboratory \\ (EMI), Mohammadia's School of Engineering \\ Mohamed V University, BP: 765, \\ Ibn Sina, Rabat-Morocco
}

The modeling of this new generation of power supply for a magnetron passes necessarily by the modeling and the dimensioning of its own new HV transformer with magnetic shunts.

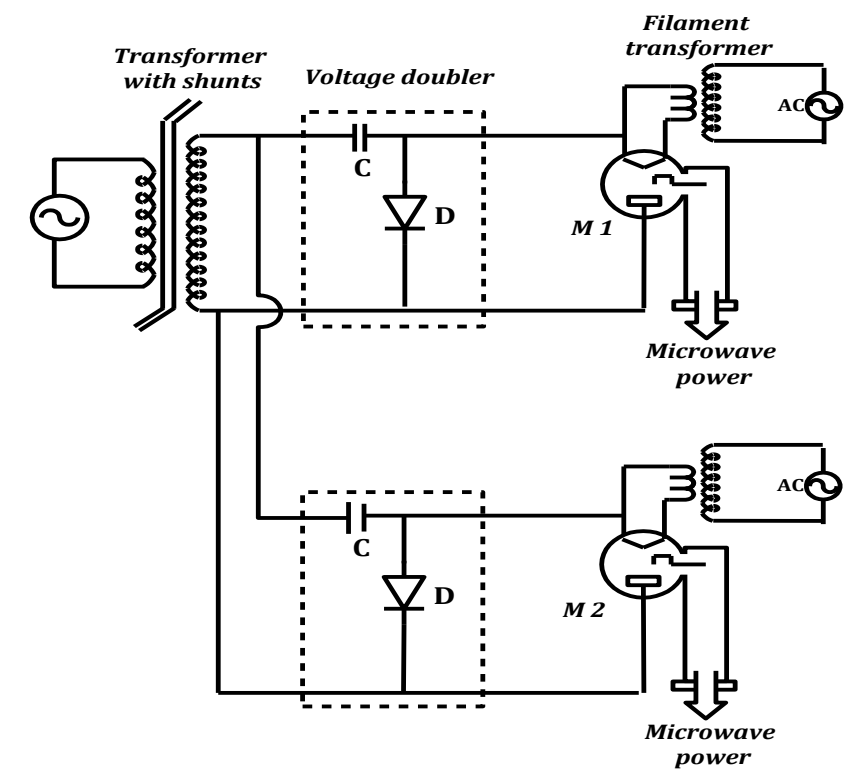

Fig. 1. New single-phase high voltage power supply for $\mathrm{N}=2$ magnetrons (Amperex Technology)

Our objective in this paper is on the one hand, to treat the modeling of the single-phase power supply designed currently to power normally, in nominal mode, one magnetron which is Moulinex brand. On the other hand, basing on this power supply to treat the modeling, for the first time, of the new power supply for $\mathrm{N}=2$ magnetrons using the tool MatlabSimulink. The paper is organized as follows:

Firstly, we discuss the modeling of the single-phase power supply currently used in the microwave generators. The modeling with Matlab-Simulink uses the power supply of the model developed by Mr. Chraygane of the transformer which is a $\pi$ quadruple. The results will be compared with those obtained experimental. 
Secondly, we present a new method validation of the $\pi$ model of the single-phase HV transformer for microwave generators with $\mathrm{N}=2$ magnetrons. This model has been tested in simulation software digital Matlab-Simulink. The signals obtained will be compared to the experimental measurements.

Thirdly, for the first time, we treat the possibility of the operation of this new system in case of failure of one or two magnetrons. This which allows to obtain relative to the current device gains in space, volume, cost of implementation and maintenance and makes this new device more economical while ensuring the process of controlling the current in each magnetron.

\section{Modeling of the CuRRent Power Supply for ONE MAGNETRON}

The modeling already developed [1-11] of a single-phase HV power supply for one magnetron 800 Watts- $2450 \mathrm{MHz}$ (Figure 2) is to model essentially the special HV transformer with magnetic leakage which ensures the stabilization of the means anodic current in the magnetron.



Fig. 2. Current power supply for one magnetron (Amperex technology)

The equivalent model of the selected transformer will be integrated into the overall scheme of the power supply to be adapted to the modeling of the whole system with MatlabSimulink.

The equivalent circuit should translate the behavior of the whole power including the magnetron and the transformer with shunts. The simultaneous solution of the electric and magnetic equations of the whole system is too complex and the solution can be only digital (Matlab-Simulink) that analytical, with the possibility to study the choice of materials and dimensions of the transformer with possible optimization.

The figure 3 shows the incorporation of the $\pi$ equivalent circuit of the transformer in the power supply resulting from the electric and magnetic equations of its operation. The advantage of this model is in its single-phase equivalent circuit referred to the secondary, which seems more comfortable to study the operation of the transformer with Matlab-Simulink. This model is called as natural because each inductance, with iron core, is based on the reluctance, therefore the permeability of a very specific part of the magnetic circuit supposed fictitiously closed on which are coiled $\mathrm{n}_{2}$ turns (secondary).
The immediate relevance of this model is to assign at each inductance a non linear relation "flow-current" of the form $\boldsymbol{n}_{2} \boldsymbol{\phi}(\boldsymbol{i})$ from the geometrical parameters of a specific portion of the magnetic circuit, allowing translating its real operation in non linear mode.

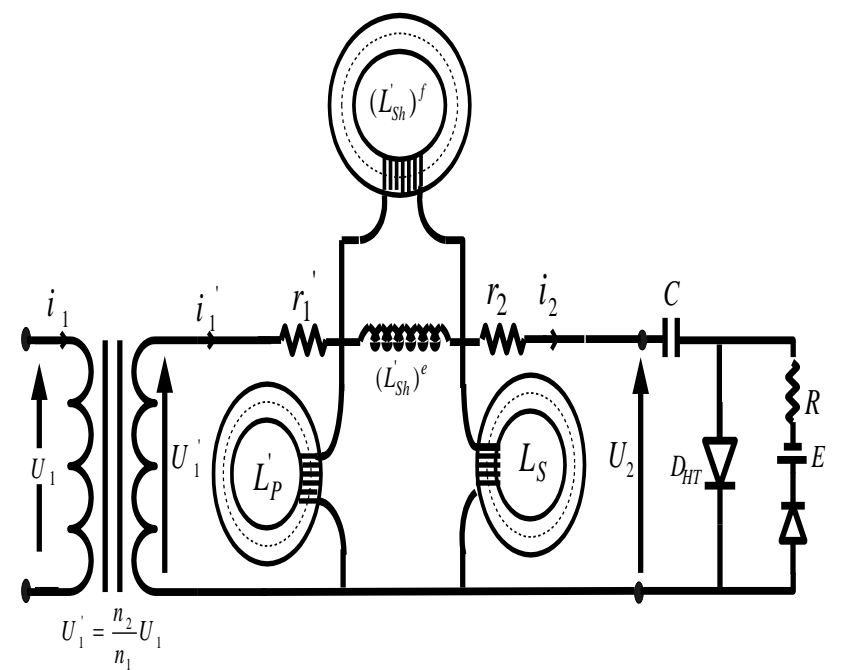

Fig. 3. П quadruple model of the transformer leakage referred to the secondary

To perform this modeling [1], [3],[4] we have sought to integrate the model of the transformer in the power circuit from the source to the magnetron (Figure 3), where we represented the microwave tube by its equivalent circuit deduced from its electrical characteristic that is formally similar to that of a diode with dynamic resistance of $350 \mathrm{Ohms}$ and threshold voltage $\mathrm{E} \approx 3800$ volts.

The elements of the model, in particular the non linear inductances, were determined from the magnetic characteristics of plates and the geometrical dimensions of the transformer. Each element of a saturable portion of the magnetic circuit, of section $S$ and of medium length $\boldsymbol{l}$, is represented by its inductance $\boldsymbol{L}(\boldsymbol{i})=\boldsymbol{n} \boldsymbol{2} \Phi(\boldsymbol{i}) / \boldsymbol{i}$ where the quantity $\boldsymbol{n}_{2} \Phi(\boldsymbol{i})$ and its corresponding current $\boldsymbol{i}$ can be determined from the curve $\mathrm{B}(\mathrm{H})$ of the material used and the geometrical elements using the relations:

$$
n_{2} * \Phi=n_{2} * B * S \& i=(H * \ell) / n_{2}
$$

To validate this model, we have carried out tests on a microwave generator composed of the following elements:

- A HV transformer with magnetic shunts characterized by: $\mathrm{f}=50 \mathrm{~Hz}, \mathrm{~S}=1650 \mathrm{VA}, \mathrm{U}_{1}=220 \mathrm{~V}$, and $\mathrm{U}_{2}=2330 \mathrm{~V}$ (resistance of the primary referred to the secondary r' ${ }_{1}=100 \Omega$, secondary resistance $r_{2}=65 \Omega$, number of primary turns: $\mathrm{n}_{1}=224$, number of turns in the secondary $\left.\mathrm{n}_{2}=2400\right)$.

- A condenser with a capacity $\mathrm{C}=0.9 \mu \mathrm{F}$ and a high voltage diode DHT.

- A magnetron designed to function under an approximately voltage $\approx 4000 \mathrm{~V}$ 
To obtain its nominal power, it needs an average intensity Imean $\approx 300 \mathrm{~mA}$, but without exceeding the peak value of its current (Ipeak <1,2 A).

In addition, the data from the manufacturer made it possible to extract the values $\mathrm{E}=3800 \mathrm{~V}$ and $\mathrm{R}=350 \mathrm{Ohm}$.
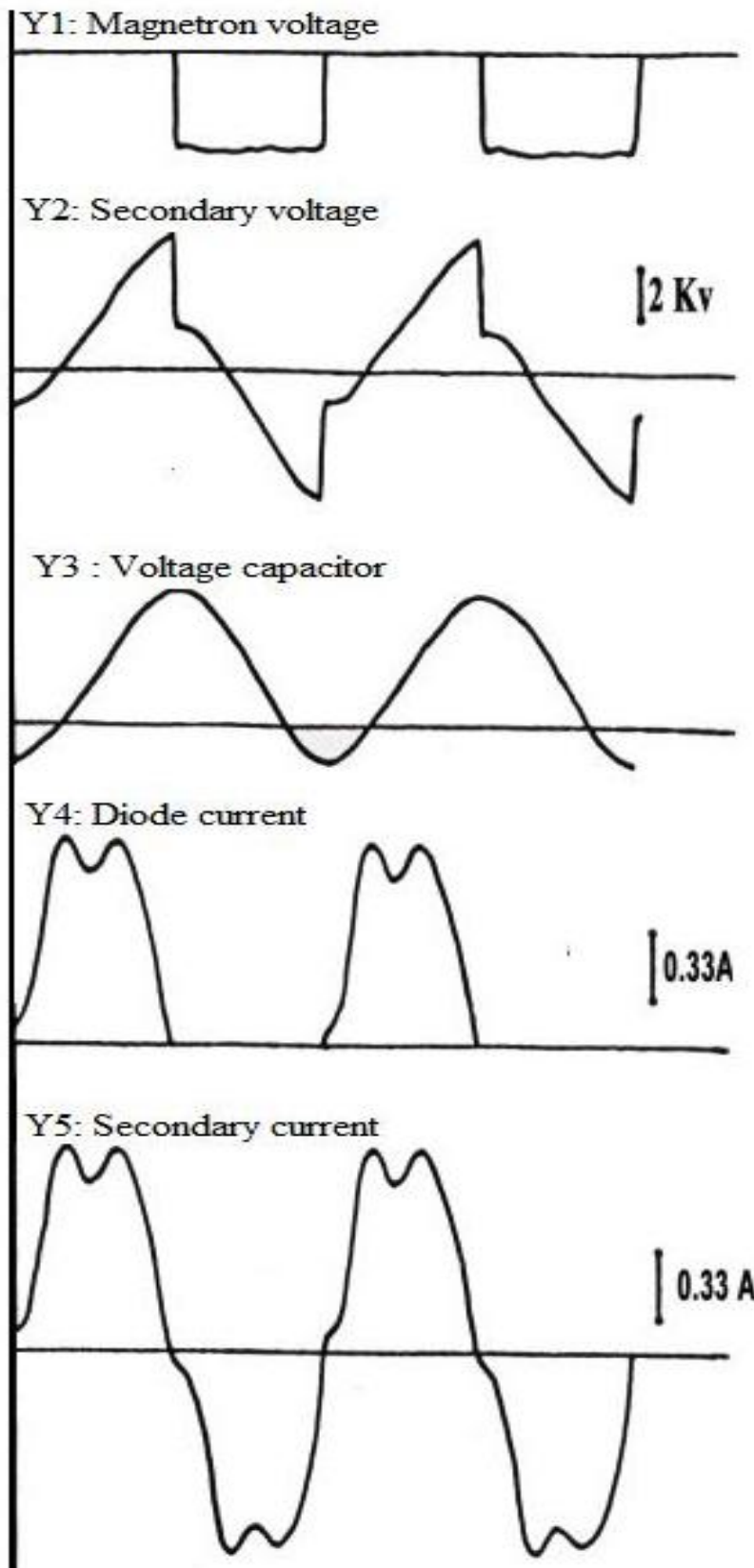

Y6: Current magnetron

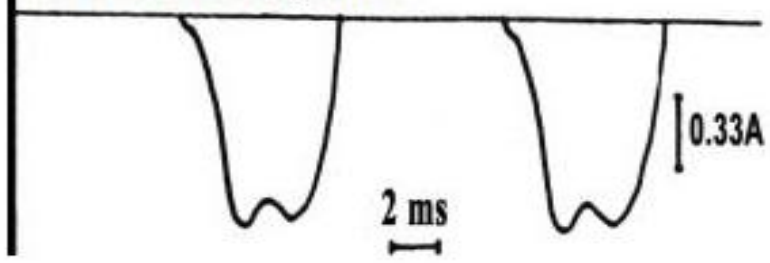

Fig. 4. A. Concordance of the experimental waveforms of currents and voltages (nominal mode)
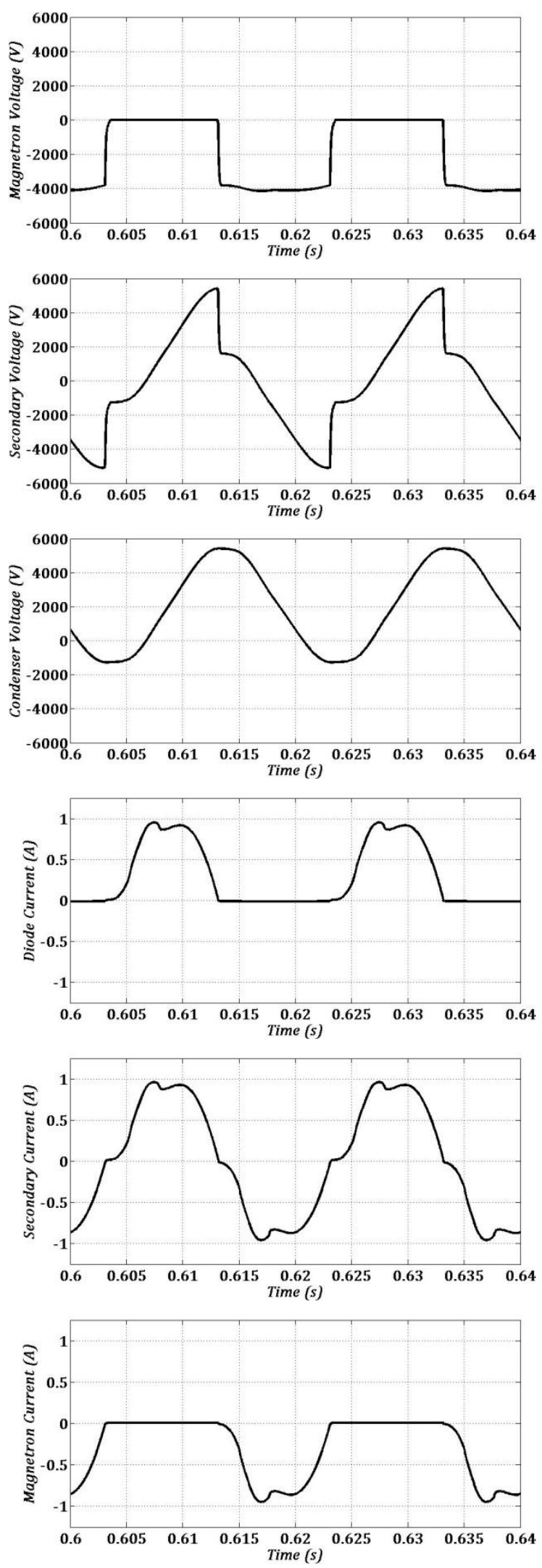

Fig. 4. B. Concordance of the theoretical waveforms, obtained by MatlabSimulink, of currents and voltages (nominal mode) 
The figures $4 \mathrm{~A}$ and $4 \mathrm{~B}$ show that in nominal operation $\left(\mathrm{U}_{1}=220 \mathrm{~V}\right.$ and $\left.\mathrm{f}=50 \mathrm{~Hz}\right)$ the results of the simulation by Matlab-Simulink of the device, in non linear regime, are in concordance with the forms of the experimental waves observed in these same conditions. Indeed, between values peak to peak, the relative differences will never exceed $4 \%$.

Taking into account the precision of various data and the acceptable tolerances on operation of the magnetron, the validity of the modeling using Matlab-Simulink was satisfactory. On the other hand, the stabilizing effect of the magnetron current has been verified with respect to the variations of the primary voltage of $10 \%$ of the nominal voltage $( \pm 20 \mathrm{~V})$.

\section{Simulation the Model of the New HV Power SUPPLY UNDER MATLAB-SIMULINK}

The modeling previously simulated [13-15] of the new HV power supply for two magnetrons 800 Watts-2450 MHz (Using The EMTP code) is to model essentially its special HV transformer with magnetic leakage. This transformer ensures the stabilization of the average anodic current in each magnetron. Integrated in an overall scheme of the new HV power supply for $\mathrm{N}=2$ magnetrons, it is suitable for the modeling the whole by a powerful tool for the numerical calculation Matlab-Simulink.

The equivalent diagram must translate the behavior of the whole, including the two magnetrons and the transformer cannot be separated from the external circuits. Too complex to be analytical, the solution can be only digitally using suitable software (Matlab-Simulink).

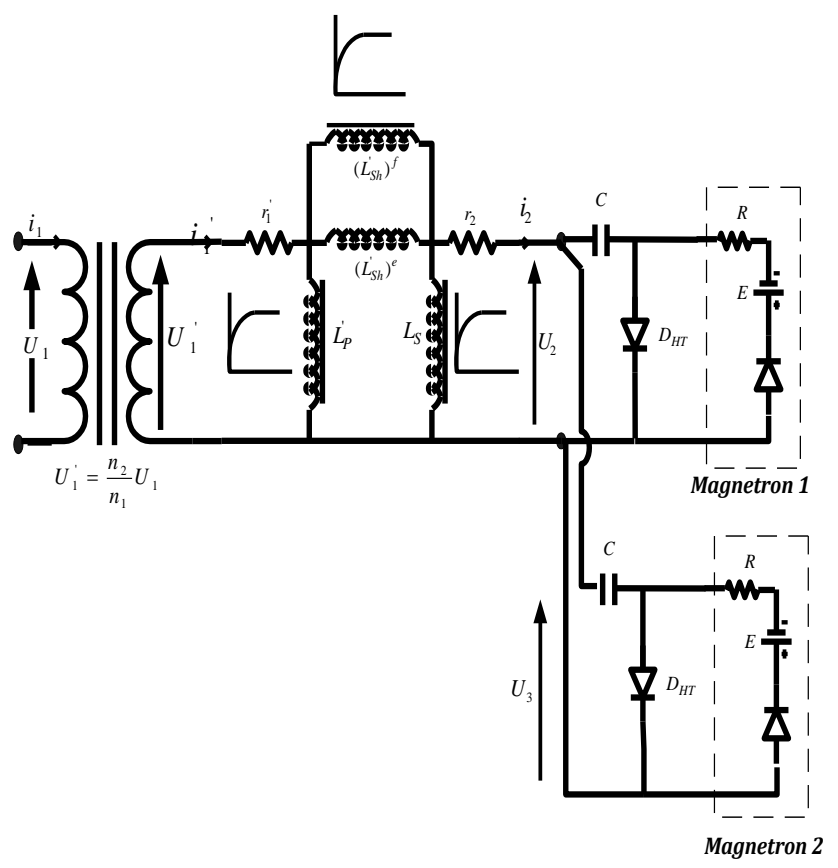

Fig. 5. New power supply for $\mathrm{N}=2$ magnetrons: Validation of the modeling with Matlab-Simulink

The figure 5 shows the integration of the model of the new transformer in the circuit of the new HV power supply from the source to the magnetrons.
Each inductance of this model is a function of the reluctance of the portion of the magnetic circuit that it represents. The simulation by Matlab-Simulink, in non linear regime linked to the saturation of magnetic circuits, is possible. Then each non linear inductive element is represented by its characteristic, depending on the relation:

$$
n_{2} * \Phi=n_{2} * B * S \& \quad i=(H * \ell) / n_{2}
$$

Under matlab-Simulink each inductance is represented by a block diagram (figure 6) and its elements are the following:

- An integrator allows you to deduct the flow from the voltage measurement.

- A function called Loockup table: this is a block which the input-output relation is defined by the user. In the dialog box, which is created when you click on the icon of the LUT, it defines point by point the relation input-output. It is here the couple of values $(\mathrm{i}, \Phi)$ deducted from those $(\mathrm{H}, \mathrm{B})$ and the geometrical data for the three inductances.

- An imposed current source.

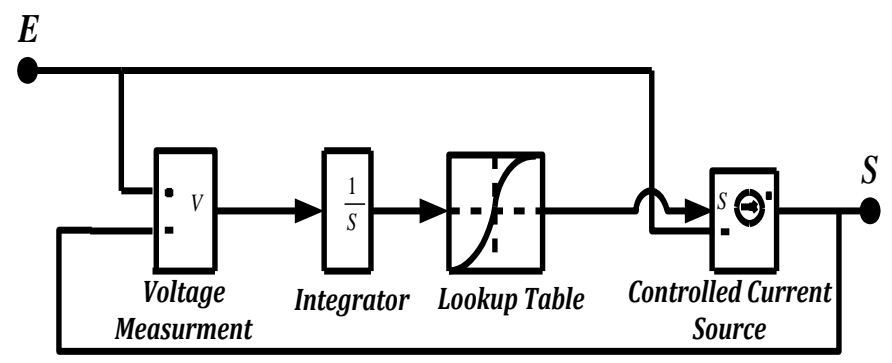

Fig. 6. Block Diagram of a non-linear inductance in Matlab-Simulink.

Thus, the figure 7 shows the overall scheme of the HV power supply for two magnetrons simulated using the software Matlab-Simulink.

We validate this model by comparing the results of simulations with those obtained from the tests already made [13-15] on a generator microwave composed of the following elements:

- A HV transformer with magnetic shunts characterized by: $\mathrm{f}=50 \mathrm{~Hz}, \mathrm{~S}=1650 \mathrm{VA}, \mathrm{U}_{1}=220 \mathrm{~V}$, and $\mathrm{U}_{2}=2330 \mathrm{~V}$ (resistance of the primary referred to the secondary $r_{1}=100 \Omega$, secondary resistance $r_{2}=65 \Omega$, number of primary turns: $\mathrm{n}_{\mathbf{1}}=224$, number of turns in the secondary $\left.\mathrm{n}_{2}=2400\right)$.

- Two voltage doublers which each one is composed of a condenser with a capacity $\mathrm{C}=0.9 \mu \mathrm{F}$ and a high voltage diode DHT.

- Two identical magnetrons which each one is designed to operate under a voltage of about $4000 \mathrm{~V}$. For its nominal power, it needs an average intensity Imoy $=300 \mathrm{~mA}$, but without exceeding the peak current may destroy it (Imax $<1.2 \mathrm{~A})$. 


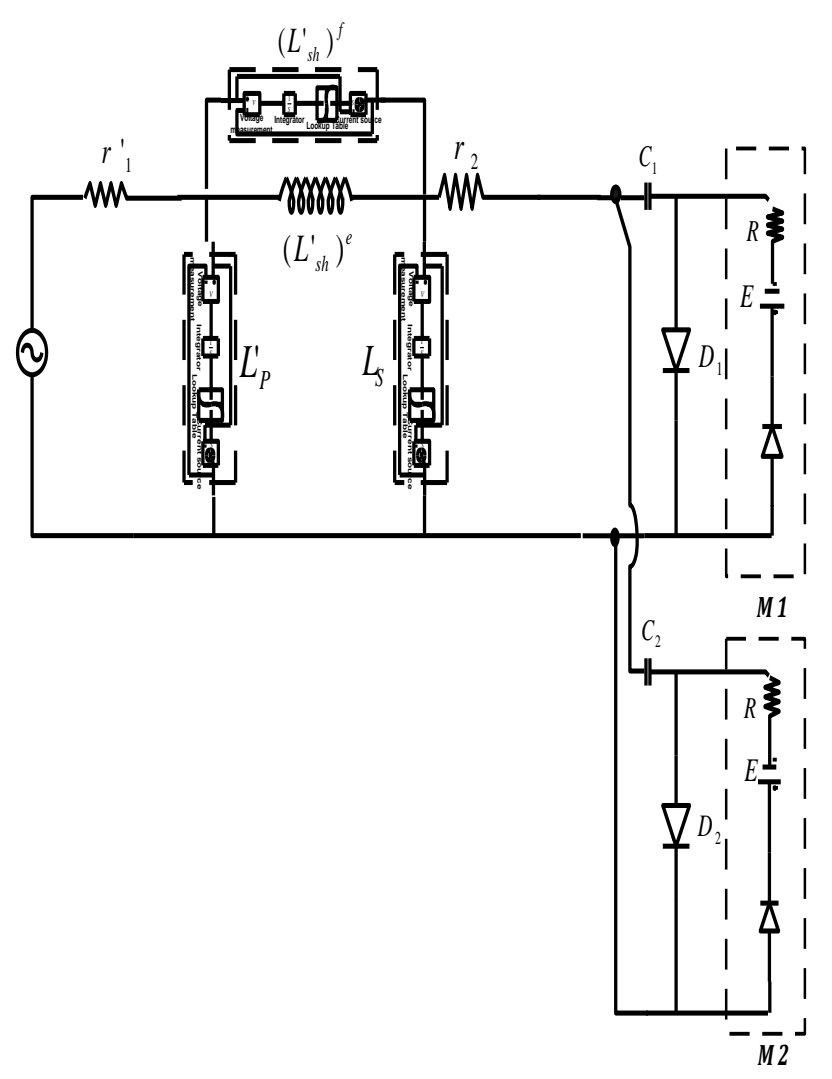

Fig. 7. Circuit of the new HV power supply for $\mathrm{N}=2$ magnetrons simulated using Matlab-Simulink code in nominal mode (non-linear regime)).

The figures 8 and 9 resulting from simulation of the device by Matlab-Simulink and those obtained in practice are in accordance. The peak current magnetron obtained by MatlabSimulink (-0.96A) that remains close $-1 \mathrm{~A}$ after practical results. Indeed, from peak to peak value, the relative differences never exceed $6 \%$. The simulation was satisfactory by MatlabSimulink.

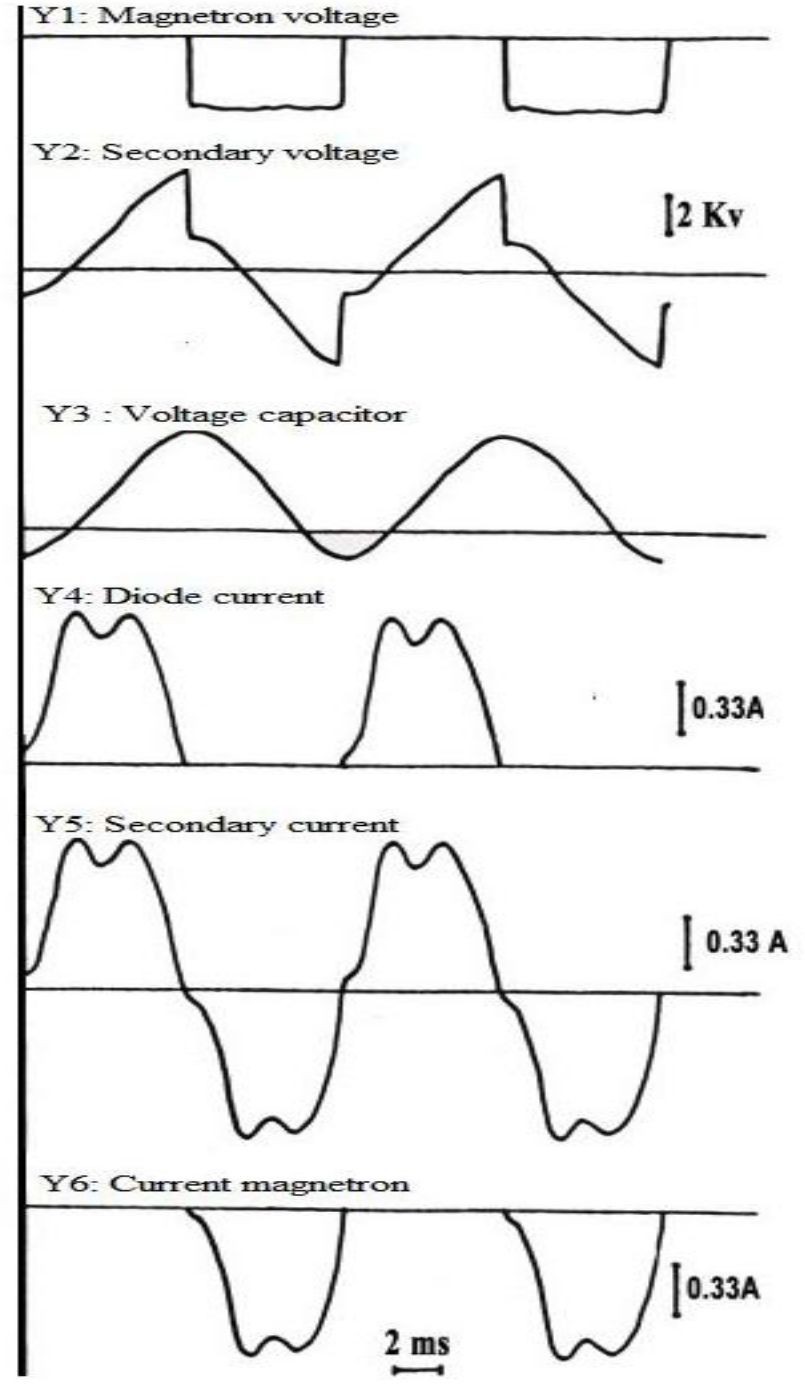

Fig. 8. Experimental waveforms of currents and voltages (nominal mode) 

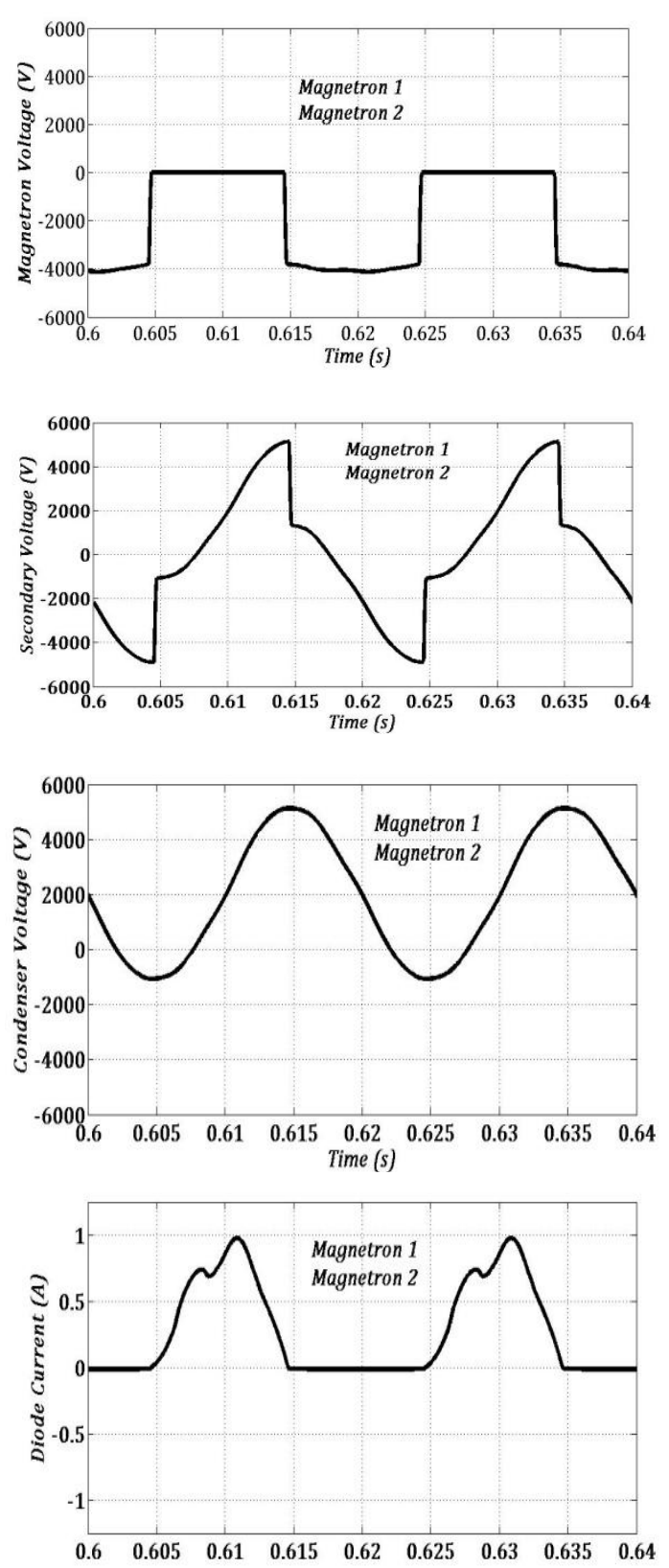
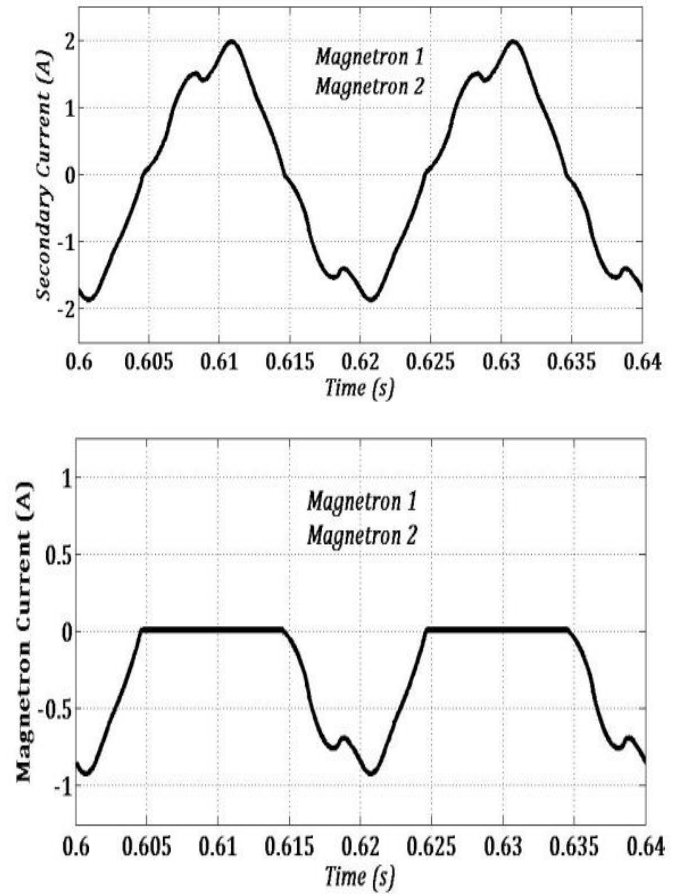

Fig. 9. Simulation with Matlab-Simulink code: waveforms of voltages and currents (nominal mode)

\section{VirificATION OF FUNCTIONING OF THE NEW POWER SUPPLY IN CASE OF FAILURE}

The study of operation of two magnetrons is performed. Now we are going to deal with a study which is the first of its kind in this area, the case where the one of the two or the tow magnetrons fails. We will repeat the simulation and see the curves of currents and voltages using the code MatlabSimulink to envisage the influence of magnetron failure on the operation of the remaining magnetron.

\section{A. Case of one magnetron in failure}

The feasibility study of the operation at the nominal mode of this new system of figure 10 was undertaken. It is to highlight if it is possible to supply a single magnetron which the other is in failure. 


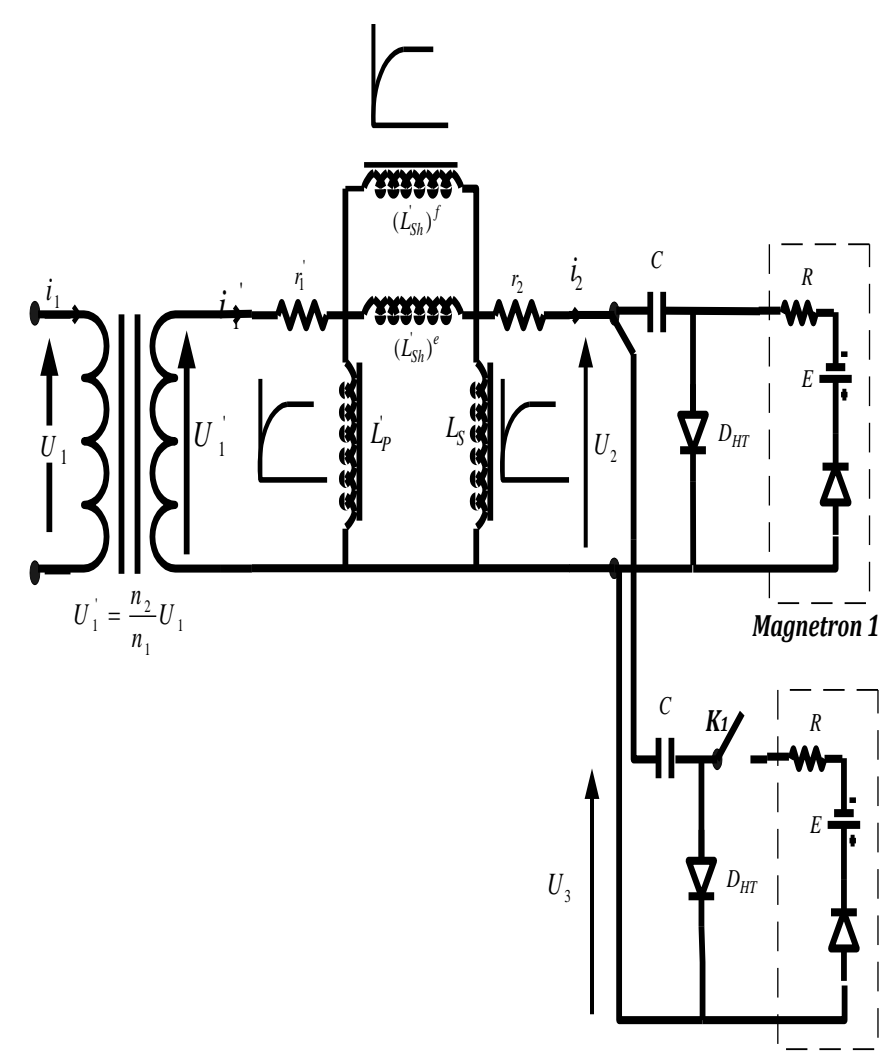

Magnetron 2

Fig. 10. Simulation of the circuit of the HV power supply using the code Matlab-Simulink in non linear regime for one magnetron on and the other off.

The simulations with Matlab-Simulink the mounting of the figure 10 have helped to raise the temporal oscillograms of the currents and the voltages of the figure 11. The diagram of this figure was simulated to account for the operation of the new power supply for a microwave generator able to deliver, in this case, under $220 \mathrm{~V}$ the full power $800 \mathrm{Watt}$ useful at $2450 \mathrm{MHz}$.

We note that the signals obtained for the magnetron in operation are identical to those in normal operation (without fail) of a conventional power supply with a single magnetron. This confirms the absence of interaction between the magnetrons.

The operating point of the magnetron in operation is therefore not more disturbed, which crucial for a stabilized power supply with current. In addition, the failure of one magnetron does not affect the operation of the remaining magnetron. It suffices to replace the magnetron off by a new magnetron.

\section{B. Case of two magnetrons in failure}

Now we are going to treat the case where the two magnetrons are in failure. We are going to repeat the simulation and visualize the curves of currents and voltages using Matlab-Simulink code to envisage the influence of the magnetrons in failure on the normal operation.
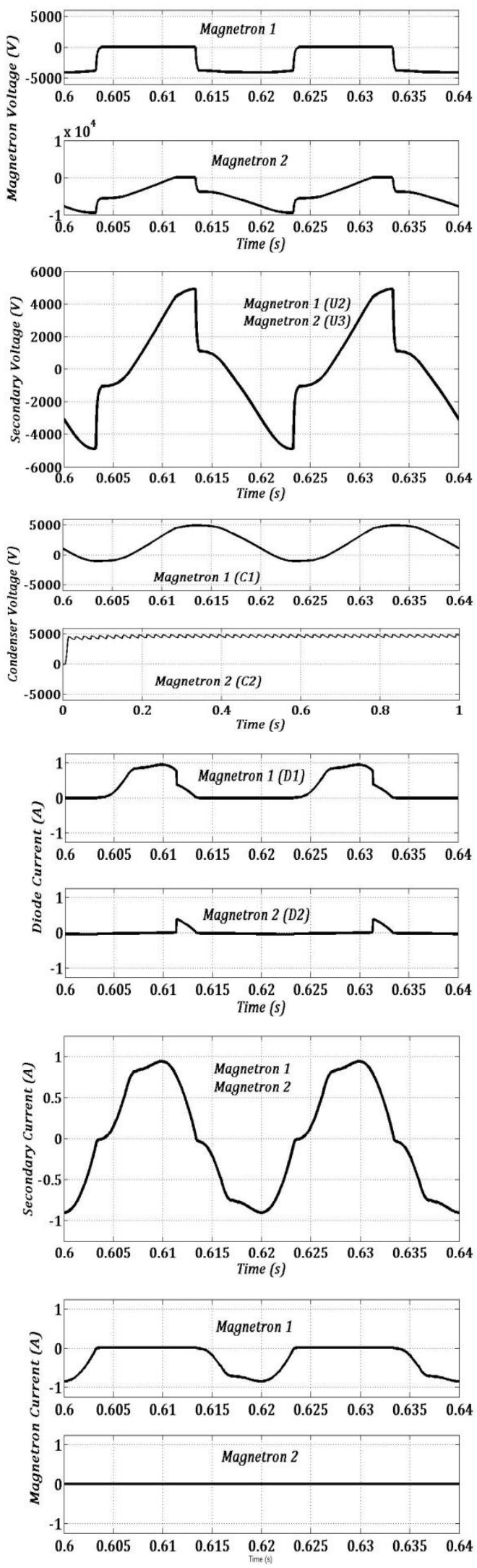

Fig. 11. Oscillograms of currents and voltages of the modeled circuit during the simulation in non linear regime with Matlab-Simulink code $\left(\mathrm{M}_{2}\right.$ in failure $)$ 


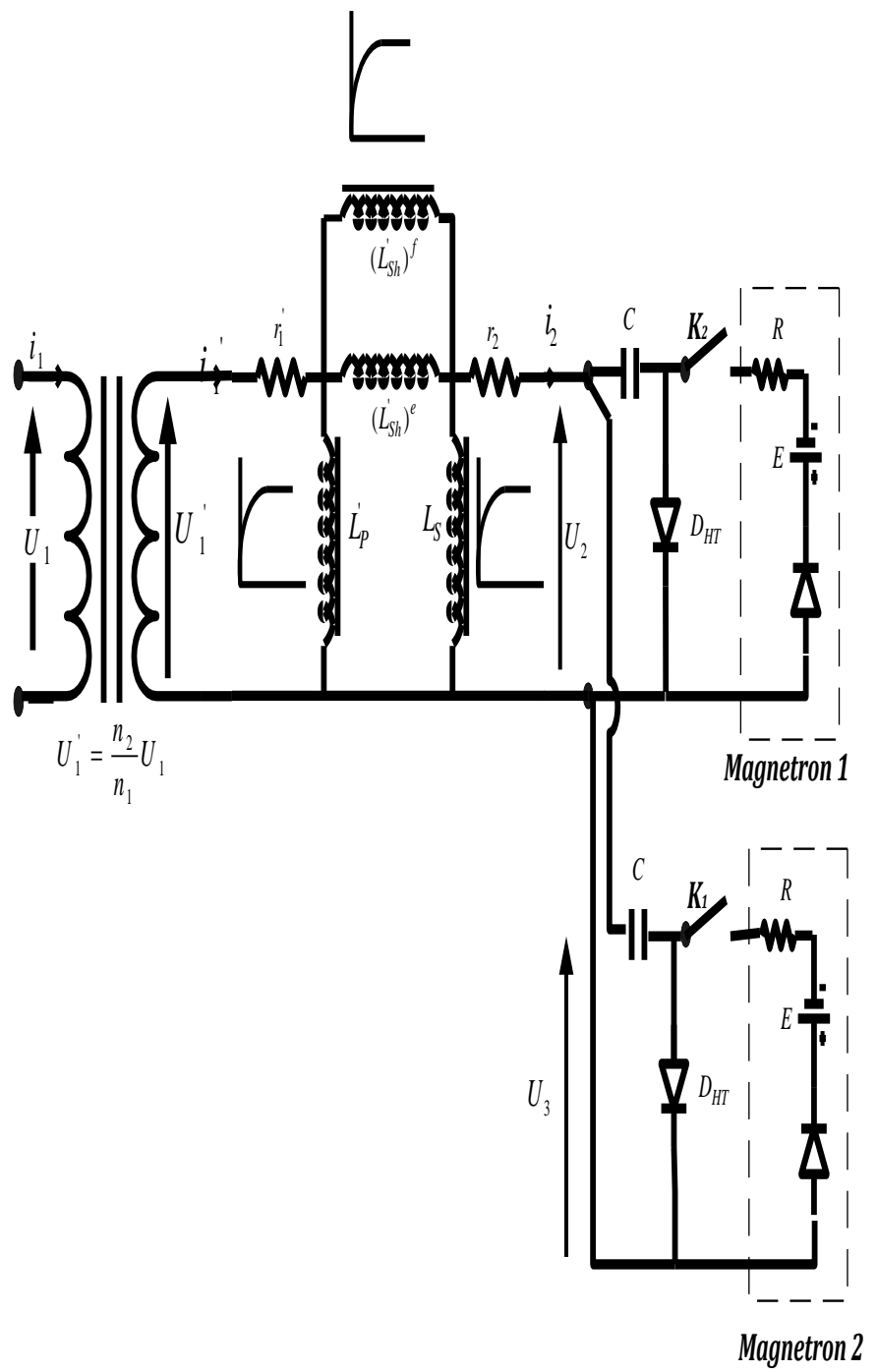

Fig. 12. Simulation circuit of HV power supply using the code MatlabSimulink in non linear regime for two magnetrons in failure.

Fig. 13. From the non linear characteristics already established of each inductance using Matlab-Simulink code, we simulated the electrical behavior of the HV circuit of the power supply in the Figure 12 where the two magnetrons are off. The oscillograms obtained during this simulation are represented in the Figure 13.

The results in Figure 13 demonstrate that the failure of the tow magnetrons $\mathrm{M}_{1}$ and $\mathrm{M}_{2}$ does not disturb the normal operation of the new transformer. So the new system can work without any problems while respecting the constraints recommended by the manufacturer.

The study of operation at the nominal mode of the new power system with two magnetrons in the case of a failure is conclusive. The conclusive study of the new power supply will certainly push us to undertake the study of a new power supply with several magnetron $(\mathrm{N}>2)$, which will allow without doubt reduce the volume, the weight and the electrical wiring and therefore guarantee a decrease in the cost of implementation and maintenance of microwave generators.


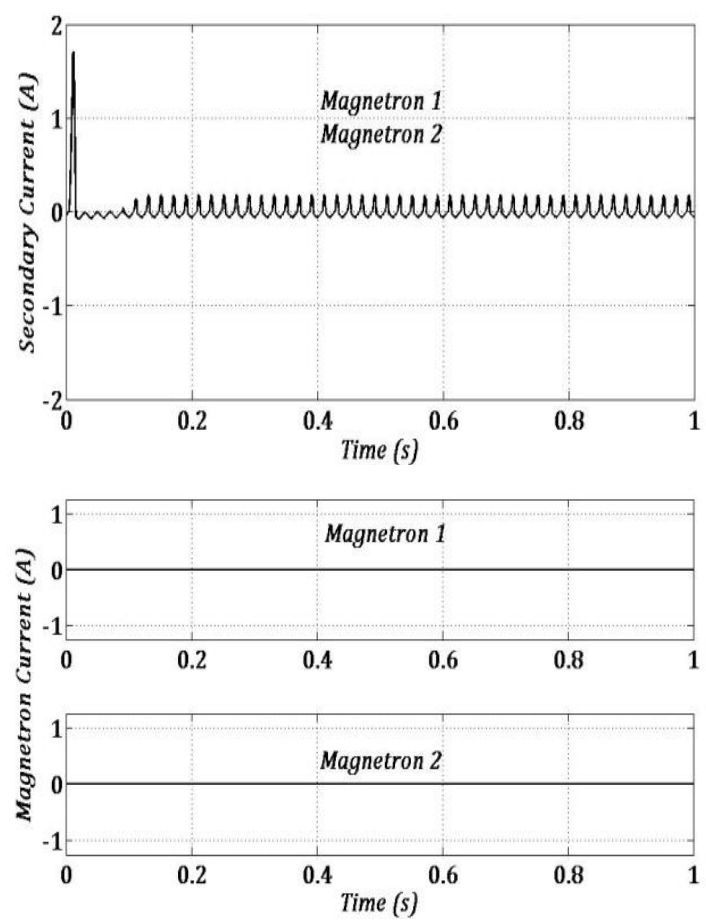

Fig. 14. Oscillograms of currents and voltages of the modeled circuit during the simulation in non-linear regime with Matlab-Simulink code $\left(\mathrm{M}_{1} \& \mathrm{M}_{2}\right.$ in failure)

\section{CONCLUSION}

The modeling using Matlab-Simulink code of the nominal operation of a new HV power supply for microwave generators with two magnetrons is conclusive. This new type of power supply can deliver up to $2 * 800=1600$ Watts Useful at 2450 $\mathrm{MHz}$ after his own adequately sized transformer with magnetic shunts.

The observations made using the Matlab-Simulink code show an excellent agreement between the simulated and the real tests. This code has confirmed the validity of the model in the non linear regime. On the other hand, the failure of one of the two magnetrons not affects the operation of the remaining magnetron.

As perceptive, this work can also be done similarly to the case of the same type of HV power supply for several magnetrons each power output 1000 Watts or 1200 Watts at $2450 \mathrm{MHz}$, which contributes to the development of the effective modeling of a new systems power for several magnetrons 800 Watts, 1000 Watts or 1200 Watts at $2450 \mathrm{MHz}$ for microwave generators using in industrial applications.

\section{REFERENCES}

[1] Chraygane M, Modélisation avec EMTP d'une nouvelle génération d'alimentation haute tension monophasée pour générateurs micro-ondes à magnétrons destinés aux applications industrielles, Thèse de doctorat d'état, Université IBN ZOHR Agadir, Maroc, n 113/07 (2007)

[2] Dorgelot E.G., Philips Technishe Rundschau, Vol. 21934 (1980) 103109

[3] Chraygane M, Modélisation et optimisation du transformateur à shunts d'une alimentation haute tension à magnétron pour générateurs microondes $800 \mathrm{~W}-2450 \mathrm{Mhz}$ destinés aux applications industrielles, Thèse de doctorat, Université Claude Bernard Lyon I, France, $n^{\circ} 189$ (1993)
[4] Chraygane M, Teissier M., Jammal A. et Masson J.P Modélisation d'un transformateur à shunts utilisé dans l'alimentation H.T d'un générateurs micro-ondes à magnétron, publication, journal de physique III, France,( 1994) 2329-2338

[5] Teissier M., Chraygane M., Jammal A. et Masson J.P , Leakage Flux Transformer Modelling, Communication, International Conference on Electric Machines, ICEM'94, Paris, (1994)

[6] M. Chraygane, M. Ferfra, M. El Khouzaï, B. Hlimi, étude de l'état magnétique interne global du transformateur à shunts d'une alimentation pour générateurs micro-ondes à magnétron destinés aux applications industrielles, Télécom'2003 et 3ème JFMMA-Marrakech. Comm., (2003) 436-439.

[7] M. Chraygane, M. Ferfra, M. El Khouzaï, B. Hlimi, Vérification expérimentale de la loi de conservation des flux du transformateur à shunts d'une alimentation pour générateurs micro-ondes à magnétron destinés aux applications industrielles, RNJCP4-Casablanca. Comm., (2003) 6-7.

[8] Chraygane, M. Ferfra, B. Hlimi, Modélisation d'une alimentation haute tension pour générateurs micro-ondes industriels à magnétron, Revue 3EI, 41 (2005) 37-47.

[9] M. Chraygane, M. El Khouzaï, M. Ferfra, \& B. Hlimi, Etude analytique de la répartition des flux dans le transformateur à shunts d'une alimentation haute tension pour magnétron 800 Watts à $2450 \mathrm{Mhz}$, J. of PCN, 22 (2005) 65-74.

[10] M. Chraygane, M. Ferfra, \& B. Hlimi, Etude analytique et expérimentale des flux du transformateur à shunts d'une alimentation pour magnétron 800 Watts à $2450 \mathrm{Mhz}$, J. of PCN, 27, (2006) 31-42.

[11] M. Chraygane, M. Ferfra, B. Hlimi, Détermination analytique des flux et des courants du transformateur à fuites d'une alimentation haute tension à magnétron pour générateurs micro-ondes industriels 800 Watts à 2450 Mhz, J. of PCN, 40 (2008) 51-61.

[12] Aguili $\mathrm{T} \&$ Chraygane M., Une alimentation originale pour générateurs micro-ondes, Revue Générale de l'Electricité RGE n 5, France, (1990) 49-51.

[13] M. Chraygane, A. Zatni, M. Ferfra, B.Hlimi \& S. Bidar, Modélisation d'une nouvelle alimentation HT monophasée pour générateurs microondes industriels à $\mathrm{N}=2$ magnétrons, Télécom'2007 et 5ème JFMMAFès. Comm., (2007) 420-424.

[14] M. Chraygane, M. Ferfra, M.El Haziti, A.Zatni, M. Bour, M. Lharch, Modélisation et simulation du fonctionnement nominal d'une nouvelle alimentation HT monophasée pour générateurs micro-ondes industriels à N=3 magnétrons, communication, Télécom'2009 et 6ème JFMMAAgadir. Comm., (2009) 77-78.

[15] M. Ferfra, M. Chraygane, M. Fadel, M. Ould Ahmedou, Modélisation non linéaire d'une nouvelle alimentation haute tension globale de $\mathrm{N}=2$ magnétrons pour générateurs micro-ondes industriels. [Non linear modelling of an overall new high voltage power supply for $\mathrm{N}=2$ magnetrons for industrial microwave generators], J. of PCN, 54 (2010) 17-30.

[16] Hermann W. Dommel, ElectroMagnetic Transcients Program, Reference Manual, EMTP Theory Book, 1986

[17] Van Dommelen D., ATP General Introduction, Leuven EMTP Summer Course, July 1991.

[18] Minutes of the 20 th European EMTP Users Group Meeting, Leuven EMTP Center, October 28-29 th, 1991.

[19] W. Scott Meyer et Tsu-huei Liu, Alternative Transients Program (ATP), Rule Book, Canadian/american EMTP User group, 1987-92.

[20] Laurent Dubé, European EMTP-ATP Users Group e.V, Users Guide to models in ATP, April 1996.

[21] Hans K. Hoidalen, Atpdraw for Windows, Atpdraw Version 3 User Manuel (Atpdraw Installation Manual, Atpdraw Introductory Manual, Atpdraw advanced Manuel), European EMTP-ATP Users Group e.V, February 1996.

[22] Mustafa Kizilcay et Laszlo Prikler, European EMTP-ATP Users Group e.V, EEUG News, Number 3, Volume 3, August 1997.

[23] Mustafa Kizilcay et Laszlo Prikler, ATP-EMTP Beginner's Guide for EEUG Members, European EMTP-ATP Users Groupe.V, June 2000. 
[24] Emperreur G., Transformers modelling basic theory, exemples, Leuven EMTP Summer Course, Belgium, July 1991.

[25] Roguin J., Ranjamina V., Modeling of magnetic circuits with EMTP, $\mathrm{EDF}$, bulletin de la DER - série B, réseaux électriques, matériels électriques, $\mathrm{N}^{\circ} 2$, pp 23-26, 1986

[26] Capolino G. A., Simulation for powers electronics and drivers using ATP, Leuven EMTP summer course, July 1991.

\section{AUTHORS PROFILE}

NAAMA EL GHAZAL was born in Laayoune,

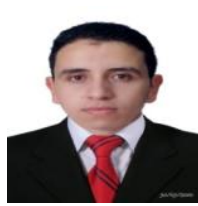
Morocco, in 08/04/1984; he received the Master Instrumentation and Telecommunications in 2010 from the faculty of sciences (Ibn Zohr University) AgadirMorocco, where he pursues his doctoral program. His research is interested in the "Feasibility study in nominal operation of a new three-phase high voltage power supply for industrial microwave generators with $\mathrm{N}$ magnetrons per phase".

ABDERRAHIM BelHAIBA was born in Agadir, Morocco, in 06/12/1983; he received the Master in 2010 in instrumentation and Telecommunications from faculty of sciences (Ibn Zohr University) Agadir-Morocco, where he pursues his doctoral program. His research is interested in the " Study of the energy balance of a new high voltage power supply $\mathrm{N}$ magnetrons per phase 800 Watts - $2450 \mathrm{MHz}$ for microwave generators used in industrial applications".
DR. MOHAMmed ChraYgane was born in Morocco in 1963; he received his thesis of doctorat from Claude Bernard University Lyon I in 1993 and his 'doctorat d'état' from Ibn Zohr University Agadir-Morocco in 2007. In 1994, he joined Technology Higher School Ibn Zohr University Agadir Morocco

(ESTA). Since this date he has been a professor in MSTI Laboratory (ESTA School Ibn Zohr University Agadir Morocco Agadir). His field of interest is modeling a high voltage power supply used for industrial microwaves generators with magnetron.

DR. Mohammed Ferfra was born in Rabat Morocco in 1965, he received the engineering degree from Mohammadia's School of Engineering (Mohamed V University) Rabat-Morocco in 1988. From 1988 to 1990, he was an assistant in the same school. From 1990 - 1993, he pursued his $\mathrm{PhD}$ program at Laval University, Quebec Canada, where he received $\mathrm{PhD}$ degree in Electrical Engineering in 1993. Since this date he has been a professor with the department of electrical engineering at EMI. His field of interest is system identification of electrical machines and modeling shunt transformer used for microwaves generators.

BOUBKER BAHANI was born in Rabat, Morocco, in 15/06/1986; he received the Master in 2010 in Instrumentation and Telecommunications from the faculty of sciences (Ibn Zohr University) Agadir-Morocco, where he pursues his doctoral program. His research is interested in the "Modeling with EMTP and Matlab of new generation of overall HV power supply for N magnetron 800 Watts-2450MHz for industrial microwave generators". 